\title{
Academia and Public Policy: \\ Towards the co-generation of knowledge and learning processes
}

\section{Mari Jose Aranguren, Miren Larrea, James R. Wilson}

Mari Jose Aranguren, Orkestra - Basque Institute of Competitiveness and University of Deusto

Miren Larrea, Orkestra - Basque Institute of Competitiveness and University of Deusto

\section{Corresponding Author:}

James R. Wilson, Orkestra - Basque Institute of Competitiveness and University of Deusto jwilson@orkestra.deusto.es

\section{Keywords:}

Universities; Public Policy; Action Research JEL Classification:

I23, 128 


\section{Abstract}

Building from the context of ongoing debates around the changing roles of universities in society, this paper contributes to analysis of academia-society interface in two important respects. First, the paper considers the underresearched subset of relations that exist between academia and public policy. It is argued that academia-policy relations bear similarities to academia-market relations; like imperfect markets, policy environments tend to be characterised by concentrations of power. Thus similar concerns to those evident in debates around the commercialisation of university activity are relevant. Second, the paper explores the issue of balance in the role of the academic with regards public policy though an auto-reflective case analysis of an emerging experience in the Basque Country region of Spain. An aim is to reflect on the very fine (and frequently controversial) line between policyoriented academic research and policy consultancy. The analysis highlights some of the benefits and issues with integrating action research principles into research projects, and suggests the significance of co-generation of knowledge and learning processes between academics and policy-makers. In turn this has specific implications for the time-horizon of relationships (long- rather than short-term) and for doctoral training (in research methodologies appropriate for such processes).

\section{Resumen}

Partiendo del actual debate vigente en torno al nuevo rol de la Universidad en la sociedad, este artículo contribuye al análisis de la interacción entre la academia y la sociedad en dos aspectos importantes. En primer lugar, el artículo aborda el análisis de un campo escasamente investigado, el de la relación entre la academia y las políticas públicas. Se argumenta que las relaciones entre la academia y las políticas corren similares riesgos que la relación entre/la academia y el mercado; tal y como ocurre con los mercados imperfectos el contexto de las políticas tiende a caracterizarse por concentraciones de poder. Por lo tanto, problemas similares a los que se dan en el debate sobre la comercialización de la actividad/universitaria, son también relevantes en este contexto. En segundo lugar, el artículo explora el tema del rol de la academia en su relación con las políticas públicas a través de un ejercicio de autoreflexión sobre el análisis de un caso emergente en la Comunidad Autónoma del País Vasco. El objetivo consiste en reflexionar sobre la línea (mucha veces controvertida) que diferencia la investigación académica orientada a las políticas y la consultoría de las políticas públicas. El análisis destaca algunos de los beneficios que la integración de los principios de la investigación-acción en los proyectos de investigación puede generar y sugiere la relevancia de los procesos de co-generación de conocimiento y aprendizaje/entre los académicos y los responsables de diseño de las políticas públicas. Esto tiene implicaciones sobre el horizonte temporal de las relaciones (más a largo plazo que a corto) y sobre las necesidades de formación de estudiantes de doctorado (en metodologías de investigación apropiados para estos procesos).

\section{Laburpena}

Gaur egun Unibertsitateak gizartean izan behar duen paperaren gainean pil- pilean dagoen eztabaidan oínarrituz, artikulu honek unibertsitate eta gizartearen artean gauzatu beharreko harremanen inguruan bi ekarpen egiten ditu. Batetik, oso gutxi aztertua den alor bat aztertzen du, akademia eta politika publikoen arteko erlazioa. Akademiaren eta politika publikoen arteko erlazioak akademia eta merkatuaren arteko erlazioen antzeko arriskuak dituela agerian jartzen da. Izan ere, merkatuaren kasuan merkatu ez perfektuek botere indarraren kontzentrazio arazoak sortzen dituzten antzera, politika publikoen alorrean ere boterearen kontzentrazioak ematen dira. Beraz, unibertsitateko jarduerak merkaturatzearen inguruko eztabaidan ematen diren arazoak esanguratsuak dira unibertsitate eta politika publikoen harremanen alorrean ere. Bestetik, artikuluak akademiak politika publikoen alorrean izan behar duen papera aztertzen du horretarako Euskal Autonomi Erkidegoko iniziatiba berri batean oinarritutako auto-hausnarketa bat eginez. Politika publikoen inguruko kontsultoria eta politika publikoen gaineko ikerketaren arteko desberdintasunean sakontzea da lan honen helburua, nahiz eta desberdintasun hau askotan agerian jartzeko zaila izan. Eginiko analisiak ikerketa-ekintza metodologietan oinarritutako ikerketen printzipioak ikerketan erabiltzeak eta ikerlariek eta politiken diseinuan maila desberdinetan parte hartzen duten pertsonek dituzten ezagutzak konbinatuz eta elkarrengandik ikasiz ezagutza berria sortzeko prozesuek dakartzaten abantailak azpimarratzen ditu. Guzti honek harremanek denboran izan behar duten iraupenean (epe luzera gehiago motzera baino) eta doktoregoko ikasleen prestakuntza beharretan (prozesu hauetarako egokiak diren ikerketa metodologietan) eragina du. 


\section{INTRODUCTION}

The role of universities in society has become a key area of debate in recent years, coinciding with movement towards a more globally-integrated economy in which processes of learning and knowledge generation are widely recognised as central to competitive advantage. Alongside the traditional functions of educating and conducting research, the importance of broader interface between university and society has been emphasised in concepts such as 'systems of innovation', the 'triple helix' of industry, government and university and the 'entrepreneurial university'. In the context of the market-capitalist system that characterises most places today, moving closer to society in practice implies moving closer to market forces. This has raised awareness of potential dangers; in particular with regards the potential loss of critical analysis of societies' problems from a distance, independent of the often narrow influences that are characteristic of imperfect markets. Such concerns are often expressed in terms of challenges to 'academic freedom'. As reforms to the funding and governance of universities imply greater interaction between academics and market forces, there are argued to be impacts on how academics plan and carry out their teaching and research activities.

Building from the context of ongoing debate around such concerns, this paper contributes to analysis of the role of universities in society in two important respects. First, we consider an under-researched subset of university-society interface of relevance largely for the social sciences; that between academia and public policy. We argue that policy-academia relations bear similarities to market-academia relations in that, like imperfect markets, policy environments tend to be characterised by concentrations of power. Parallel but nuanced concerns to those generally applied to university research and teaching can therefore be highlighted in this specific axis of university-society relations. Second, we explore the issue of balance in the role of the academic with regards public policy. Here we build our analysis around an emerging experience from the Basque Country region of Spain in which the authors are involved. An aim is to reflect on the very fine (and frequently controversial) line between policy-oriented academic research and policy consultancy. This line is 
particularly relevant when seeking to balance academic research with policy agent interaction. We focus specifically on the integration of action research principles into research projects, where our analysis highlights processes of cogeneration of knowledge and learning between academics and policy-makers as a key axis of interface. In turn this has specific implications for the time-horizon of relationships (long- rather than short-term) and for doctoral training (in research methodologies appropriate for such knowledge co-generation processes), among other issues.

The paper is structured as follows. Section II provides context by analysing the changing roles of universities and academics in society. We highlight some of the concerns that have arisen in response to these very recent and ongoing changes, and set the specific frame of analysis by introducing the academiapublic policy interface as an influential subset of university-society relations. In Section III we analyse the issue of balance in this interface between academics and policy-makers, building our analysis around reflections on the authors' involvement in an emerging set of experiences in the Basque Country. Finally, in Section IV we conclude with series of recommendations from our analysis. These include proposals for clearly defining the line between policy-oriented academic research and policy-consultancy in terms of aims and processes; for ensuring the development of relationships between academics and policy agents that go beyond short, discrete projects; and for developing improved training in methodologies that address some of the problems associated with policy-oriented academic research.

\section{THE ROLES OF UNIVERSITIES AND ACADEMICS IN SOCIETY}

\subsection{Towards a 'third mission' of Universities}

In general terms universities, and by extension the academics within universities, have traditionally been acknowledged as playing two primary and strategic roles in society. Firstly, with regards teaching: facilitating the development of knowledge and skills among people (human capital development). Secondly, with regards research: generating and diffusing 
potentially useful research ideas that may lead directly or indirectly to innovations in socio-economic outputs and processes. Both roles are strategic in the sense that they are important contributors to processes of socioeconomic development. Indeed, elements of both human capital and research have featured strongly in the development of theoretical and empirical literature seeking to explain economic growth (Lucas, 1988; Romer, 1989; Mankiw et al., 1992; Temple, 1999). Moreover, following the pioneering work of Becker (1964), the economic and social returns from higher education are frequently calculated and analysed. The OECD, for example, has integrated such analysis into its influential annual Education at a Glance set of indicators (OECD, 2007). ${ }^{1}$

However in recent years interest in the role of universities in socio-economic development processes has intensified. In particular, there has been strong growth in research analysing the significance of universities for local and regional economic development processes, accompanied by increasing demands from regional actors on their universities (Karlsen, 2007). The emphasis is typically oriented towards combining both of the traditional human capital and research roles of the university in a more active contribution to regional development. This intensification of concern around an active regional role of the university corresponds broadly with the advance of processes of globalisation. While globalisation itself can be variously defined (Sugden and Wilson, 2005), it is generally associated with the increasing integration of socioeconomic relationships across geography, facilitated at a great pace in recent years by new transport and communication technologies. Thus for Scholte (2000, p. 46), for example, "the proliferation and spread of supraterritorial - or what we can alternatively term "transworld" or "transborder" - connections brings an end to what could be called "territorialism", that is, a situation where social geography is entirely territorial”. This 'de-territorialisation' of socioeconomic relationships at a global level, however, has simultaneously served to emphasise the importance of proximity-based relationships rooted in regional and local systems (Morgan, 2004). Authors such as Ohmae (1995), Storper

\footnotetext{
${ }^{1}$ See Psacharopoulos (1994) or Psacharopoulos \& Patrinos (2002) for updates of key findings regarding returns to investment in education; also Blundell et al. (2000) for an example of an econometric analysis.
} 
(1997), Cooke and Morgan (1998) and Scott (1998), for example, have been influential in emphasising regions as important economic and policy units in an increasingly globalised world. Indeed, trends in globalisation in general have helped fuel a burgeoning literature in regional studies. ${ }^{2}$

Part of the reason for growing interest in the role of universities in this context is the widespread acknowledgement of the critical importance of processes of knowledge and learning as sources of competitive advantage. Dunning (2000, p. 8), for example, expresses a widely accepted view when he argues that "over the last three centuries, the main source of wealth in market economies has switched from natural assets (notably land and relatively unskilled labour), through tangible assets (notably buildings, machinery and equipment, and finance) to intangible created assets (notably knowledge and information of all kinds)". Moreover, the theory of 'stages' of economic development proposed by Porter (1990) and adopted by the World Economic Forum in its annual Global Competitiveness Report makes a related distinction between 'factor-driven', 'efficiency-driven' and 'innovation-driven' economies, suggesting that knowledge and learning processes are even more critical in the most advanced economies (World Economic Forum, 2008).

Thus it is no co-incidence that the role of universities in society, particularly in advanced economies, has become a key area of analysis as globalisation has intensified, and that this has taken place with an increasingly regional frame of reference. Indeed, universities are today seen as key actors in moving territories towards what Morgan (1997) terms 'learning regions' (Feldman, 2001; Lazzeretti and Tavoletti, 2005). Thus a 'third mission' of universities has been identified and progressively explored (Laredo, 2007). Building on the long acknowledged functions of educating and conducting research, the importance of the interface between university and local economies has been emphasised in specific concepts such as 'systems of innovation' (Freeman, 1987; Lundvall, 1992; Nelson, 1993; Cooke et al., 1998), the 'triple helix of industry, government and university' (Etzkowitz and Leydesdorff, 1997) and the 'entrepreneurial

${ }^{2}$ See, for example, Pike (2007), opening a special issue of Regional Studies reflecting on current issues and debates in the field. 
university' (Etzkowitz, 1997, 2004). Together, these present a powerful imperative for universities to seek to move closer to the societies in which they are situated, thereby stimulating the hypothesised benefits from knowledge flows in interaction with other (public and private) socio-economic agents.

\subsection{Academia and Market Forces}

The development of this third mission of universities has occurred alongside a further important and relatively rapid development. In many places the higher education sector is increasingly recognised for its tangible contribution as a potent productive sector per se, and one with significant spillovers, for example from the consumption activity of students. In particular, universities are acknowledged for their potential to generate significant export revenues, both from the attraction of overseas students and from their establishment of a presence in foreign markets, alongside rents from the sale of research. The importance of universities in this 'market competitive' sense has been present for many years, but has come to the fore recently. This can be seen, for example, in the explicit targeting of higher education by Singapore's Economic Development Board with the aim of creating an Asian Pacific hub of world class universities. It can also be seen clearly in the UK, where a recent report highlights the growing importance of university production, which accounts for export earnings of $£ 3.6$ billion and the employment of $1.2 \%$ of the total UK workforce (Kelly et al., 2006). Indeed, using a broader industry definition, Lenton (2007) reports that the total value of education and training exports to the UK economy in 2003/4 was greater than both the financial services and automotive sectors. ${ }^{3}$

Thus universities themselves are increasingly aware of their commercial potential, and are often under funding pressures to exploit that potential, at a time when they are being expected to play a key role in catalysing regional economic development processes. In this sense, closer interaction with society is frequently framed in terms of market relationships with other socio-economic

3 See 'Education worth more to British exports than banking', The Guardian, September $18^{\text {th }}$ 2007. 
agents (Lundvall, 2002). For example, the concept of the entrepreneurial university is arguably most developed in the United States, where the influential Baye-Dole Act of 1980 granted ownership of intellectual property rights to research institutions, thus creating a strong incentive for universities to exploit their research in the marketplace. Furthermore over time interaction with the market has permeated most areas of universities' operations. Bok $(2003$, p. 3) terms this process 'commercialisation', defined as "efforts to sell the work of universities for a profit." He argues that today "opportunities to make money from intellectual work are pursued throughout the university by professors of computer science, biochemistry, corporate finance, and numerous other departments. Entrepreneurship is no longer the exclusive province of athletics departments and development offices; it has taken hold in science faculties, business schools, continuing education divisions, and other academic units across the campus" (Ibid., p. 3).

Bok is reflecting on US experience, ${ }^{4}$ but such trends are also at particularly advanced stages in Australia, New Zealand and the UK for example (Kelsey, 1998; Roberts, 1999), and are spreading rapidly in other advanced economies. Wilson (2009) argues that the commercialisation of universities can itself be split into four inter-related, yet distinct, processes: (i) marketisation, the permeation of market mechanisms in the relationships between higher education and society; (ii) globalisation, the increasingly global scope of the operations of universities; (iii) corporatisation, the evolution of internal corporate structures, practices and principles within universities; (iv) privatisation, the explicit transfer of ownership of activities from the public sector to private, for-profit corporations. While universities find themselves at different stages of each of these processes, which themselves manifest different implications, these changes are generating significant debate around some of the problems associated with universities moving too close to market society (Aronowitz, 2000; Bailey, 2008; Bok, 2003; Grönblom \& Willner, 2009; Levin \& Greenwood, 2008; Lundvall, 2002; Sparkes, 2007; Sugden, 2004; Wilson, 2009).

4 Bok was previously President of Harvard University and Dean of Harvard Law School. 
The balance to be found in the interface between academia and market society raises significant challenges that are only just beginning to be explored given the (historically) relatively rapid changes in universities during the last 2-3 decades. In particular, there is argued to be a danger that universities may progressively lose their ability to develop knowledge and critical analysis of society and its problems from a distance, independent of the often narrow influences that are characteristic of imperfect markets. Indeed, an additional important role for higher education is sometimes identified alongside (and integrating) its functions in teaching and research; that of developing capacity for independent, critical thinking among the citizens of a society. Barnett (1997) argues, for example, that critical thinking is a defining concept of the Western university, developing this into a concept of 'critical being'. This is defined as the ability for people to engage critically with the world and with themselves, developing powers of critical self-reflection and critical action. In this sense universities have a role in creating spaces for the nurturing and development of critical analysis of society, among both students and academics.

Much of the concern around the move towards commercial rationale as guiding principles in both learning and research derives from the view that adherence to market forces can damage the capacity of universities to provide the space conducive to rigorous, independent activity. The development of a market for research, for example, can play to existing concentrations of power and undermine the freedom of academics to pursue the research that they independently consider to be most desirable. As academics strive for research funding from both public and private sources, a logical outcome is not to design projects according to their own perspectives on desirable research agendas and then seek the possibility of appropriate funding. Rather, there is a tendency to design and conduct research from the outset according to the explicit (or perceived) objectives of those who fund the research. There may even be temptations to manipulate research findings, so as not jeopardise future funding opportunities.

Put another way, as academics become more concerned with 'supplying' research to 'customers', there is effectively pressure to ensure that the 'product' 
matches expectations. Such pressures have the potential to fundamentally change the nature of research, leading to a more deterministic, outcomeoriented process that is arguably less free, open-ended and independent. Similar arguments can be made with regards learning. As market pressures are translated to academics dealing with programme design, admissions and marking processes, for example, there is a temptation to make judgements on market rather than academic grounds. From the students' perspective too, being taught as 'customers' rather than as people engaging in a learning process becomes expressed in expectations and behaviour that are more outcome-determined and less open.

The embracing of a third mission of universities built around closer interaction with other agents in society thus raises significant questions in terms of the impacts of commercial rationale, both internally and externally, on academic processes. In particular, as universities themselves become more dependent on their own generation of funds, the arguments above suggest a clear need to develop appropriate mechanisms, checks and balances to ensure that academic rationale fundamentally guide the development of research and learning agendas. That is not to say that academics should retreat from society back into their ivory towers; rather that the independence provided by those towers should be recognised alongside the need to interact more effectively with society. This is particularly so given that powerful concentrations of interests for example those of transnational corporations - are often expressed in imperfect market environments, leading to what Cowling and Sugden (1998) term 'strategic failure'. Universities can provide an important and independent counter-balance to these powers, or they can themselves seek to mimic the behaviour of transnational corporations (Sugden, 2004).

\subsection{Academia and Public Policy}

Based on the general arguments explored above, our focus in this paper is on examining the implications for a specific subset of the university-society interface, that between academia and public policy. Our focus is thus not on the role of the university within the triple helix or the innovation system as a whole, 
which incorporates its relationship with a range of public and private agents, involving both market and non-market relationships. Rather we are interested specifically in the interface between academic research and the government agents responsible for designing, implementing and evaluating public policies. Moreover, this implies that our focus is primarily on the social sciences (economics, business, sociology, political science ...). This marks a further change from much of the traditional analysis of the third mission in terms of innovation systems and the entrepreneurial university, where the natural focus is on transfer of science- and engineering- based knowledge between academia and industry.

Theoretically there is a direct parallel between the general arguments presented in the previous sub-sections and the specific nature of the academia-public policy interface. The arguments presented thus far are framed in terms of the pressures of market forces on the independence of academic processes. The reason why this is potentially problematic is precisely because markets are acknowledged as being imperfect, characterised by concentrations of power (Baran and Sweezy, 1966; Tirole, 1988; Cowling and Sugden, 1998). Thus as academics increase their interaction with market society there is a danger that academic activity may be skewed to reflect the interests of those concentrations of power. Moving to the academia-public policy interface, we can observe that policy environments too are characterised by concentrations of power. Democratic mechanisms are only imperfect in representing the whole range of interests in society and providing a constraint to the power of certain groups. Moreover it is clear that political power and economic power are frequently interrelated. ${ }^{5}$ This would imply that there are similar dangers that academic processes may be captured towards certain interests as academics engage more closely with public policy agents.

\footnotetext{
5 A striking example at international level can be seen in the 'trilateral commission', formed in 1973 with the aim of using collective influence to safeguard the interests of Western capitalism (Sklar, 1980; Marchak, 1993). Marchak (1993: 110) notes that the Commission was influential in establishing summit meetings between dominant nations, and that the "participants have made major decisions about ... IMF and World Bank policies, decisions they are empowered to make because together they control voting rights in those organizations."
} 
In particular, there is growing concern among some academics as to where the line between policy-related academic research and policy consultancy should be drawn. Consultants clearly provide a 'product' that must in some sense be tailored to the expectations of the purchaser (the policy-maker): outputs are well-defined from the beginning; and future contracts are likely to depend on providing solutions that are both sensitive to the interests of the particular client and that encourage a certain 'dependence' of the client. Academic research, however, cannot be framed as a 'product' in the same way: it is a flexible process whose outcomes and even methodologies are often uncertain at the time of first specifying the research question; and it must be truly independent if it is to attract respect among peers and be considered genuinely 'academic'. Despite these clear differences, however, as academic research moves closer to policy environments the distinction can become blurred. This is particularly so in a context where there are often strong pressures to interact on both sides: on academics to bring in external research funding and to be seen to be fulfilling their 'third mission'; and on policy-makers to validate (or at least be seen to) their policies with 'independent' academic expertise.

The heterogeneity of policy environments suggests that there is likely to be a strong contextual element to analysis of these tensions. Firstly, there are different levels of public policy with which academics interact; from the most local at the level of the municipality, through regional, national and finally international or global institutions. Secondly, there are different areas of policy (macroeconomic, microeconomic, social, cultural ...), although Layard (2006) argues convincingly that these cannot in fact be analysed in isolation and require collaboration between different branches of social sciences. Finally, in each particular policy environment the culture of academic engagement with policy-makers will have a distinct history and tradition, determined in part by the institutional characteristics of the university system and the government agencies, and also potentially by the characteristics of key individual relationships between researchers and policy agents.

This heterogeneity and specificity suggests the importance of case analysis as a methodology through which to explore issues of balance in the academia-public 
policy relationship. Moreover, we consider auto-reflective analysis to be particularly methodologically appropriate in exploring the line between consultancy and research, where conflicting pressures continually require consideration and response by academics themselves. Thus the remainder the paper is structured around reflections on the authors' experiences with a specific case of academia-public policy interface in the Basque Country region of Spain. The level of public policy is hence delimited to the regional level (in line, for example, with the analysis of Karlsen (2007)), and in terms of policy area the case is centred on what is broadly termed 'competitiveness' policy. This is particularly appropriate given that policy autonomy for almost all areas of microeconomic competitiveness policy rest with the Basque Country government rather than at national level. In terms of institutional characteristics, the case examines the establishment and early development of the Basque Institute of Competitiveness, a research institution explicitly designed as a bridge between academic research and both firms and policy agents. In practice until now most interaction has taken place between researchers and policy agents, and it is these ongoing experiences that form the basis of the analysis.

\section{EXPLORING THE ACADEMIA-PUBLIC POLICY RELATIONSHIP}

\subsection{The Basque Institute of Competitiveness}

The Basque Institute of Competitiveness was founded in March 2006 as an initiative of the Deusto Foundation, an institution devoted to making scientific knowledge available to society. It is a research centre based at the University of Deusto (a private, Jesuit-run university), and initially funded for 4 years by a group of stakeholders that include SPRI (the Society for the Promotion of Industry of the Basque Country Autonomous Government), the Provincial Council of Gipuzkoa, and several firms. It was established with the aim of supporting activity from public administrations, socioeconomic agents and all of the universities in the Basque Country in generating real improvements in the competitiveness of the region. Within this broad field, research within the centre 
has been focussed in three sub-areas: (i) 'clusters, regional development and innovation'; (ii) 'entrepreneurship'; and (iii) 'strategy'. ${ }^{6}$

Researchers forming the Institute were drawn initially from different research groups at the University of Deusto, and maintain around 30\% of their annual hours complement for teaching in the University. Researchers have also been recruited directly by the Institute, with agreements in place so that these academics can also become faculty members and engage in certain teaching activities within the University. The Institute currently has 29 staff (including doctoral students), 23 of whom are directly engaged in research and researchsupport activities. While the research of the centre has a strong territorial focus, this is explicitly designed to be complemented by engagement in international research networks, the aim being to ensure that research on the Basque Country reaches an international audience and that cutting-edge research from around the world permeates analysis of Basque competitiveness. There has hence been an effort to recruit researchers from outside of the Basque Country and of Spain, and research activities have been developed with various international partners and networks. ${ }^{7}$

The stated mission of the Institute to support the activity of a range of socioeconomic agents in enhancing the competitiveness of the region has been operationalised explicitly through three inter-related activities: research, interaction and teaching. ${ }^{8}$ The combination of these is seen as crucial for engaging both with the frontier of international knowledge on competitiveness and competitiveness policy, and with the actual situation of the Basque Country. Thus research, interaction and teaching combine in impacting through 'actions' on the competitiveness of the Basque Country Autonomous Community and in contributing through 'outputs' to the international pool of knowledge. Our own interpretation of this general model of operation is illustrated in figure 1.

\footnotetext{
${ }^{6} \mathrm{~A}$ fourth area of 'welfare' has been defined but not yet developed.

7 For example, the European Network on Industrial Policy (EUNIP), the Global Entrepreneurship Monitor (GEM), the Max Planck Institute for Economics, the China Europe International Business School (CEIBS) and the Institute for Strategy and Competitiveness at Harvard University.

${ }^{8}$ In Spanish, these translate as the three i’s of 'investigación', 'interacción' and 'instrucción'.
} 
Figure 1: The Basque Institute of Competitiveness Model of Operation

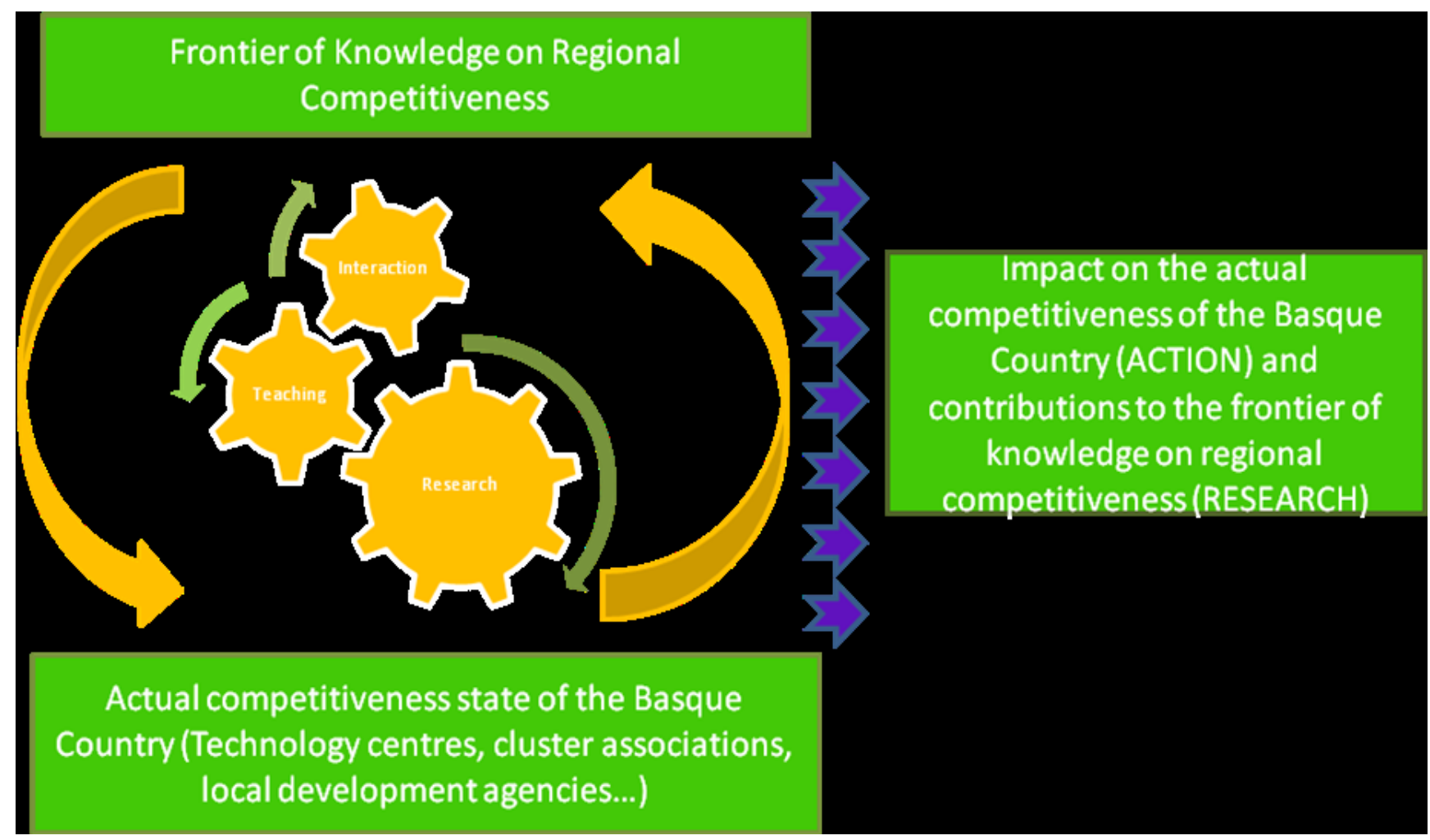

\subsection{Different Approaches to Combining Interaction and Research}

Within this overall structure various methodologies are employed by different academics and groups of academics within the Institute in undertaking their activities; there is freedom by individual academics to select how they work. Nevertheless there has emerged discussion among researchers in particular surrounding questions of balance between 'research' and 'interaction', and the ideal forms that these activities should take individually and/or in combination. 'Teaching' is seen as less controversial, probably because academics are very used to combining research and teaching, while explicit recognition of interaction as an academic activity alongside research is more novel.

Simplifying somewhat, across the various research projects currently underway within the Institute we can identify two broad approaches to the researchinteraction balance: 
(1) In what we might label a traditional university approach there remains a fairly clear distinction between 'research' and 'interaction'. A combination of established disciplinary research techniques are employed in the definition and undertaking of research (literature analysis, theoretical development, qualitative and quantitative analysis ...). Interaction with the users of research occurs in processes of peer-review, conference presentation, publication of articles and reports, press releases, dissemination workshops etc.. While there may be some interaction with users of research in the design phases (response to calls for research proposals, research proposal feedback, etc.), most interaction takes place in the latter stages of the research in dissemination and discussion of results. Thus there is not only a distinction between research and interaction but also a clear separation of the two processes in different phases of the projects.

(2) In what we might label an action research approach the distinction between 'research' and 'interaction' is considerably more blurred. Mixes of the same established disciplinary research techniques are employed in the definition and undertaking of research (literature analysis, theoretical development, qualitative and quantitative analysis ...), but throughout the process a consistent interaction with the agents at whom the research is targeted is maintained. Thus systematic interaction of the form of meetings, participatory workshops and focus groups with agents, for example, are present alongside more traditional forms of interaction in the proposal and dissemination stages. A result is that the targets of the research become an integral part of the research process itself, meaning that the distinction between research and interaction is far less clear.

Individual researchers within the Institute do not generally adopt one of another of these approaches exclusively and neatly. However, while all researchers come from a tradition of research in mode 1 and continue much of their activities along these lines, there is a small group of researchers (which include the 
authors of this paper) who have recently begun to explicitly develop research projects in mode 2 . In practice both approaches demonstrate different and complementary responses to the requirements placed on academic researchers in an institute with an explicit mission to conduct research that supports the activities of government and other socio-economic agents in enhancing a territories' competitiveness. Moreover, in their different forms of interaction, both approaches carry risks of crossing the line that separates academic research from consultancy. In the case of mode 1, the danger is the more traditional one of ensuring independent analysis while respecting the interaction with (politically and/or financially) powerful interests in the proposal and dissemination phases. In the case of mode 2 the danger is often argued to be heightened given the systematic nature of the interaction, but on the other hand it can be argued that such interaction enhances the sophistication with which academic research can truly engage with and impact on society. For both of these reasons, in the next sections we reflect on our experiences as researchers in developing projects in mode 2.

\subsection{Learning from Action Research}

The group of researchers who have explicitly sought to develop projects according to the mode 2 approach to research and interaction have sought to learn from the principles of action research, and to frame certain projects explicitly as action research projects. Following Greenwood and Levin (2007) we understand action research as socio-economic research carried out by a team that encompasses a professional action researcher and the members of an organization, community or network (stakeholders) who are seeking to improve the participants' situation. In line with Reason and Bradbury (2008: 1), it is "not so much a methodology as an orientation to inquiry that seeks to create participative communities of inquiry in which qualities of engagement, curiosity and question posing are brought to bear on significant practical issues." The practical issues addressed have been mainly related to local economic development policies and the Basque Government's cluster policy, including for 
example policy evaluation issues. ${ }^{9}$ Hence participative communities of enquiry have included policy agents from the Basque government's Department of Industry, Commerce and Tourism, from local development agencies, and from the network of local development agencies (GARAPEN). In one particular research project to evaluate the cluster policy of the Basque Government, the cluster associations and firms targeted by this policy are also included in the community of enquiry (Aragón et al., 2008).

The evolution among this group of researchers towards incorporating certain principles of action research in fact pre-dates the establishment of the Basque Institute of Competitiveness. It emerged from a questioning of the impacts that researchers' policy-related research was having outside of pure academic circles. Indeed, among some there has been conscious awareness of the need to involve different forms of participation of policy agents in their research processes for several years. However, the institutional legitimisation provided by the establishment of the Basque Institute of Competitiveness has been particularly important in facilitating the realisation of more sophisticated interaction with policy agents. Some of the advantages of such interaction can be illustrated by a specific project to map potential local 'clusters' in the Basque Country.

This project was initially suggested by the administrative board of the Institute, which comprises its financing stakeholders. The proposal was to use data on numbers of establishments in different industrial sectors in each of the 250 municipalities of the Basque Country to produce a study that mapped agglomerations of specialised activity and enabled an identification of potential local 'clusters'. A team of researchers from the Institute adapted a methodology employed by a similar study in Catalonia used to map local production systems (Hernández Gascón et al., 2005), and initially set out to produce a similar report for the Basque Country. During the research process, however, it became clear that there were significant methodological difficulties in determining which

\footnotetext{
9 See Aranguren et al. (2006) for detailed accounts of the genesis and evolution of the Basque cluster policy and the establishment and role of local development agencies in the Basque Country.
} 
sectors were related; in short there was a lack of detailed local and industry knowledge among the research team. Other studies have solved this problem from a distance by interviewing a series of industry experts and then making a series of judgements. However, in this case the project coincided with awareness within the research group of: (i) a pool of local knowledge present within local development agencies and (ii) the desire of Basque Government policy-makers to introduce a sub-regional element to their cluster policy. A decision was therefore made to re-orient the project from the straightforward production of a research report based on our analysis of data, to a processoriented project involving policy agents from the local development agencies and the Basque Government.

A flexible online tool was developed by the research team to make the data available in an easy-to-use format and to provide the capability to draw geographical maps of the results. A series of 5 workshops were then held over a 5 month period with around 20 local development agency representatives. At these workshops the research team taught the policy agents the basics of the methodology, alongside some of the theoretical and practical principles of clusters and cluster policy, and worked with them as each undertook a mapping of their own group of municipalities. In a $6^{\text {th }}$ workshop the local development agencies presented their analysis to cluster policy-makers from the Basque Government as an input to ongoing considerations regarding adding a local dimension to the regionally-administered cluster policy.

As a consequence of this systematic interaction with policy agents the results of this research process have hence been quite different from those envisaged from the initial project. A disadvantage has been the lack of complete coverage of the Basque Country territory in the mapping exercise; ${ }^{10}$ although these gaps can potentially be filled by the research team in the future. However, at least four significant advantages can be identified from the interactions inherent to the adopted approach:

\footnotetext{
${ }^{10}$ The call for participation was open to all agencies with an interest. While the take-up rate was extremely good, it was not $100 \%$ and the system of local development agencies also does not have $100 \%$ coverage of the Basque territory.
} 
(1) The approach has enabled a potent combination of the theoretical and methodological knowledge of the research team with the on-theground knowledge of the policy agents. Thus when it came to making the ultimately subjective judgements about where to draw lines around agglomerations in terms of activities and location, the decisions could be made from the basis of far greater knowledge of the local industrial texture.

(2) The approach has facilitated significant learning processes on both sides as these different knowledge bases have been able to systematically interact. This has implied, for example, an empowerment of both sides in terms of knowledge that can be used in future projects.

(3) The approach has ensured that advantages can be made of synergies and work already in progress in the local development agencies in identifying potential clusters for further strategic analysis.

(4) The involvement of policy-makers from the Basque Government has opened the potential for future dialogue and closer co-ordination between policy initiatives at different geographic scales that are based often on very similar principles and processes.

This concern to integrate principles of action research in certain research projects resonates more generally with arguments made by Levin \& Greenwood (2008) with regards the future of universities. As universities have become increasingly subject to corporate forms of accountability and quality assurance they have been losing public credibility and support, in large part due to the issues highlighted in the first part of this paper. Levin \& Greenwood (2008) suggest action research as a solution for universities. They argue that its deployment is a good way to resist the full-scale neo-liberalisation of our societies because it "strengthens remaining pro-social and pro-democracy 
forces within higher education and links these to the wants and needs of a broad social spectrum of non-university stakeholders" (ibid.: 224). Indeed such arguments can also be related to the views of Bailey (2008), discussing the 'university in ruins'. He suggests that while academia today is rapidly losing its independence and sense of identity, there is little resistance from academics because they themselves are divided. Their division, it is argued, stems from the mistaken adoption of 'knowledge' as the unifying concept of the university. He suggests that 'enquiry' and 'problem-solving', which share the same logical structure in all subject areas, should be the true unifying concepts. Bailey (2008) interprets inquiry as "making tentative judgements, discovering the logical consequences of these judgements, and trying to revise them when, inevitably, inconsistencies arise". While there is no direct link made to action research, we suggest that in this notion of 'enquiry' there are strong synergies with some of its underlying principles.

Reflections on our experience with the above cited projects lead us to argue that movements towards the research principles associated with enquiry and with action research, when used effectively, and at least with regards academiapublic policy relations, can be of great help in preserving the line between research and consultancy. In a research environment that is subject to the new public management principles (Levin \& Greenwood, 2008; Grönblom \& Willner, 2009) and/or where pressures to design and publish research are required to interact with powerful external interests, there are serious dangers in crossing that line and producing research as 'product' in the mould of a consultancy relationship. Crossing the line can both play to powerful interests, potentially skewing research, and create dependence of the policy agent on the consultant/researcher. At first glance it might appear that the deeper and systematic interaction required by action research implies stronger dangers. However the interaction of this approach also brings potential for the development of qualitatively different relationships that, with appropriate safeguards, can in fact re-enforce the line, generating respect for academic independence and empowering rather than creating dependence among policy agents. In particular, we refer to the mutual understanding and respect of different viewpoints around sensitive questions that can emerge through 
participative democratic processes that facilitate the co-generation of knowledge. Indeed, Greenwood and Levin (2007: 10-11) "equate democracy with the creation of arenas for lively debate and for decision making that respects and enhances the diversity of groups", a view that can be paralleled with arguments in the political science literature around the benefits of deliberative democracy (Bohman, 1998; Elster, 1998; Habermas, 1989, 1996;). ${ }^{11}$

\subsection{Issues and Challenges in Undertaking Policy-Related Action Research}

We have sought above to reflect on some of the benefits of bringing principles of action research and enquiry to bear on policy-related academic research, in particular through facilitating processes of co-generation of knowledge among academics and policy agents. However, we can also highlight a number of recurring issues that as researchers we have been facing in seeking to combine this with the maintenance of rigour and independence in our research. Not least, for example, there are issues of dealing with the perceptions of others, where often the time spent interacting generates a view that little time is being spent on what is conventionally understood as 'research'. Below we organise our reflections on these challenges with relation to five themes.

First, there are issues related to the communication of research results and hence the impacts of action research projects. While the primary academic measurement of research quality remains the ability to publish in well-known journals, this indicator is not always aligned with the impacts that research might have in society. There is hence a tension among researchers in terms of how to approach both aims simultaneously. Knowledge that is co-generated in action research is generally difficult to present in traditional forms due to its inherent concern with the overall process of interaction as a research framework. Moreover, projects are usually 'small' in the sense that the groups analysed are reduced cases, meaning that results are difficult to empirically

\footnotetext{
${ }^{11}$ Elster (1998: 8), for example, argues that deliberative democracy incorporates two elements: "collective decision making with the participation of all who will be affected by the decision or their representatives"; and "decision making by means of arguments offered by and to participants who are committed to the values of rationality and impartiality".
} 
generalise. As a consequence researchers usually undertake research in different modes simultaneously. Furthermore, to better fit the publishing parameters of reviews, results obtained from action research projects are often reported avoiding the presentation of the methodology related to the long run process. This has at least two effects: (i) it diminishes the visibility of research results obtained by action research processes among important stakeholders; and (ii) it implies that certain important lessons learnt in the research process are not shared among academics.

Second, there are issues related to research project financing. This again concerns the long-run nature of action research processes. It is difficult to find external financing for long term processes, so such processes must usually be divided into shorter projects in order to obtain external financing. In a long term process there are moments when it is possible to define a project with well delimited goals, scope and expected results and obtain financing, but other moments when this is not possible (for instance when dialogue is proceeding to define goals). In such cases it is important that the research institution understands and supports the process (even in absence of specific financing) because researchers need to spend time also in these phases. This is sometimes difficult because there is often an institutional tendency to prioritise projects with external financing.

Third and related to the finance issue above is the issue of balancing interaction in the face of time and resource constraints. Following Greenwood and Levin (2007: 108), action research processes "demand time investments in the form of sustained communications and interactions that shape a common ground of understanding". The group of researchers engaged in action research projects at the Basque Institute of Competitiveness until recently was comprised of researchers with an exclusively academic profile. As long-term processes were developing, interaction and networking with the agents - in this case especially the local development agencies - became increasingly time-demanding, reducing researchers' space for academic reading and writing. The interactions themselves were observed to take two forms: 
(a) Knowledge intensive interactions, with a strong component of knowledge co-generation. These are mainly meetings where researchers and agents engage in diagnosing the situation, making decisions or evaluating the process. They are sometimes formally organised and at other times spontaneous.

(b) Networking intensive interactions, with a strong component of keeping the network alive. Between meetings agents usually have the commitment to work on aspects of the project, and doubts frequently arise in this process regarding tools, data, etc.. Thus there is very intense interaction to resolve queries, organise the next meetings, prepare materials, write reports on what is being done, write about the project for the website, agree what is going to be communicated to the media, etc..

One response to growing time pressures has been to incorporate a nonacademic member in the team explicitly responsible for the networking intensive interactions. This has enabled other academics to concentrate on knowledge intensive interactions and on academic reading and writing. ${ }^{12}$ However such a solution implies an understanding by the research institute of the need for different profiles of researchers, and there remain unsolved issues regarding perceptions of this role, integration into standard academic career paths, etc.. A second response to the time pressures has emerged in terms of the structuring of projects. A model has been developed whereby an initial phase of very intensive cooperation is undertaken with one association or agency to understand the problems, define a research process that responds to those problems, and assist the agent in starting actions oriented to solving those problems. Following this pilot phase, researchers have then engaged with an intermediate agent (the Department of Industry of the Basque Government or GARAPEN) so as to open the process to the rest of the associations or agencies. In this second phase, however, the interaction cannot be so intensive

\footnotetext{
12 This response is in line with Greenwood and Levin (2007: 98): "text based database analyses, narrative analysis, life histories, autobiographies, focus groups, interviews of all sorts, documentary analyses, and many other methods can and will be used and many of these will be learned by and executed by nonacademic members" of action research teams.
} 
due to time pressures, and the focus has been on training and assisting the agents in using the methodologies defined in the experimental process themselves. While we judge this approach to have been relatively effective, there is a risk that some of the 'knowing how' developed by the research team and the agents in the initial stage is not transferred in the less intensive second phase. The key issue again has been one of finding an appropriate balance between working intensively with agents and maintaining the space required for academic reflection and analysis.

Fourth, there are inter-disciplinary organisational issues. There are two key issues here. The first refers to an internal context in which some researchers are engaging in action research processes while some are not. As a result certain thematic areas of expertise, and thus certain agents, tend to be the focus of action research approaches, while others are excluded. However, real problems do not respond to disciplinary frontiers, and in this context expectations can be generated among agents who are outside of action research processes that are difficult to meet. Indeed, the exclusion of some agents because they are outside of the specific disciplinary expertise of the research team is limiting both for them, and potentially also for the agents that are included within the process. Ideally, we consider that there should be a balance of action research and traditional research processes across all of the disciplinary sub-areas to provide flexibility in the research teams that can respond to the real needs of different projects. However, this is organisationally problematic in a research environment that, rightly, takes care to respect the choices made by individual researchers with regards their agendas and methodologies. The second key issue refers to the unfeasibility of integrating all disciplines necessary to effectively solve real-world problems within one specific research centre such as the Basque Institute of competitiveness. This implies the need to develop both individual and institutional relationships that span research centres and universities within a territory, so that specific action research projects can draw on a wider pool of expertise (economists, sociologists, political scientists, geographers, etc.). 
Solutions to these problem are likely to be long term and related in particular to the fifth issue, that of training. Doctoral training programmes, certainly in Spain, and arguably more generally, are particularly weak with regards introducing students to the principles and techniques of action research processes and to research interaction across disciplines. Thus the vast majority of researchers are significantly more comfortable in employing traditional research methods within discipline, albeit with greater degrees of interaction with external agents in research design and dissemination, responding to pressures to engage with society. A balance between traditional and action research approaches and a true integration of necessary disciplinary knowledge across the spectrum of projects is thus difficult to ensure. Indeed, while many of the processes that have been developed from the Basque Institute of Competitiveness have important elements of action research, the researchers involved have never been explicitly trained as action researchers. They have developed these projects guided by intuition, common sense, and reflection on some of the methodological literature. Key challenges in our own context, therefore, are to continue to train ourselves as action researchers able to interact across disciplines, and to open up similar possibilities for doctoral students at our Universities. In particular, we suggest that doctoral programmes in the social sciences should expose students to both to the alternative methodologies offered by action research, and to debates around the dangers present in action research and traditional research processes with regards capture of the research process by powerful interests.

\section{CONCLUDING REMARKS}

In this paper we have built on an analysis of some of the general concerns that surround the changing roles of universities in society to reflect on the specific interface between academia and public policy. As in other areas of the university, academics in the social sciences are today required to play a far more active role than in the past in their local and regional policy contexts, responding in their own disciplinary niches to the so-called 'third mission' of universities. However there are two different, and often conflicting, problems that emerge as universities and their academics seek to engage more 
effectively with the societies in which they are situated. Firstly there is the issue of making an effective bridge between academic research and policy, ensuring that the process is attractive to the people involved on both sides. Secondly there is the issue of ensuring that in making that bridge, the independence of both the academic and policy processes are maintained to a sufficient degree. From the academics' perspective this can be framed in terms of treading an often difficult line between policy-related academic research and policy consultancy, the latter being more output determined and (explicitly or implicitly) sensitive to the interests of those 'purchasing' the research.

We have employed an auto-reflective case methodology to explore some of the issues that arise for academics in ensuring an appropriate balance between interaction and research. Our analysis points to a series of conclusions with relevance both for academics engaged in policy-related research and for the design of research institutes and funding mechanisms. In particular we would emphasise the benefits of facilitating processes that facilitate an open, cogeneration of knowledge between academics and policy agents. Moreover, successful knowledge co-generation processes require development over a medium to long time-frame, so as to avoid interaction being reduced to designing closed, outcome-oriented research projects that are then 'sold' to policy-makers. Long term processes also critically provide the necessary space for aims to be clearly articulated and assimilated by the different agents involved, and mutual respect over roles to be built. All of this has implications for financing, which typically takes a shorter time-horizon, suggesting the need for institutional bridging of research finance between externally-funded projects and/or for the development of long-term relationships between research centres and research funders.

In addressing resource issues we suggest that it is particularly important to bear in mind the need for researchers to be given the space to detach from processes of intense interaction and engage in academic reflection (reading and writing). This time is crucial both for ensuring an independent, critical academic perspective in the ongoing research and for enabling the development of research outputs in terms of publications that are able to generate the respect of 
peers. Finally, our reflections in the Spanish context point to the need for improved training in research methods that are explicitly designed for a world in which engagement with other socio-economic agents is expected of academics. Doctoral programmes in the social sciences should expose students to the alternative methodologies offered by action research, to the advantages of multi-disciplinary research, and to debates around the dangers present in all research processes with regards capture of the research process by powerful interests. 


\section{References}

Aragón, C., Aranguren, M-J., Diez, M-A., Iturrioz, C., Larrea, M. \& Wilson, J. R. (2008). 'Una Metodologia Partecipativa per la Valutazione della Politica dei Cluster nel Paese Basco' (A Participatory Methodology for Evaluating the Cluster Policy of the Basque Country), Sviluppo Locale, XII: 29-30, pp. 155180.

Aranguren, M-J., Larrea, M. \& Navarro, I. (2006). 'The Policy Process: Clusters versus Spatial Networks in the Basque Country', in C. Pitelis, R. Sugden \& J. R. Wilson (eds.) Clusters and Globalisation: The Development of Urban and Regional Economies, Cheltenham: Edward Elgar.

Aronowitz, S. (2000). The Knowledge Factory: Dismantling the Corporate University and Creating True Higher Learning, Boston, MA: Beacon Press.

Bailey, R. W. (2008). 'Is the University in Ruins?', Institute for Economic Development Policy Discussion Paper 2008-02, University of Birmingham, UK.

Baran, P. A. \& Sweezy, P. M. (1966). Monopoly Capital: An Essay on the American Social and Economic Order, New York: Monthly Review Press.

Becker, Gary S. (1964). Human Capital: A Theoretical and Empirical Analysis, with Special Reference to Education, New York: National Bureau of Economic Research.

Blundell, Richard, Dearden, Lorraine, Goodman, Alissa and Reed, Howard (2000). 'The Returns to Higher Education in Britain: Evidence from a British Cohort', The Economic Journal, 110: 461, F82-F99.

Bohman, J. (1998). 'Survey Article: The Coming Age of Deliberative Democracy', The Journal of Political Philosophy, 6: 4, 400-425.

Bok, D. (2003). Universities in the Marketplace: The Commercialisation of Higher Education, Princeton: Princeton University Press.

Cooke, P., Gomez Uranga, M. \& Etxebarria, G. (1998). 'Regional Systems of Innovation: Institutions and Organisational Dimensions', Research Policy, 26(4-5), 475-91.

Cooke, P. \& Morgan, K. (1998). The Associational Economy: Firms, Regions and Innovation, Oxford: Oxford University Press. 
Cowling, K. \& Sugden, R. (1998). 'The Essence of the Modern Corporation: Markets, Strategic Decision-making and the Theory of the Firm', The Manchester School, 66: 1, 59-86.

Dunning, J. H. (2000). 'Regions, Globalization, and the Knowledge Economy: The Issues Stated', in J. H. Dunning (ed.) Regions, Globalization and the Knowledge-Based Economy, Oxford: Oxford University Press.

Elster, J. (ed.) (1998). Deliberative Democracy, Cambridge: Cambridge University Press.

Etzkowitz, H. (1997). 'The Entrepreneurial University and the Emergence of Democratic Corporatism', in H. Etzkowitz \& L. Leydesdorff (eds.), Universities and the Global Knowledge Economy: A Triple Helix of University-Industry-Government Relations, London: Cassell.

Etzkowitz, H. (2004). 'The Evolution of the Entrepreneurial University', International Journal of Technology and Globalisation, 1(1), 64-77.

Etzkowitz, H. \& Leydesdorff, L. (eds.) (1997), Universities and the Global Knowledge Economy: A Triple Helix of University-Industry-Government Relations, London: Cassell.

Feldman, J. M. (2001). 'Towards the Post-University: Centres of Higher Learning and Creative Spaces as Economic Development and Social Change Agents', Economic and Industrial Democracy, 22(1), 99-142.

Freeman, C. (1987). Technology Policy and Economic Performance. Lessons from Japan, London: Pinter.

Greenwood, D. J \& Levin, M. (2007). Introduction to Action Research, second edition, London: SAGE Publications.

Grönblom, S. \& Willner, J. (2009, forthcoming). 'Destroying Creativity? Universities and the New Public Management', in S. Sacchetti \& R. Sugden (eds.) Knowledge in the Development of Economies: Institutional Choices Under Globalisation, Cheltenham: Edward Elgar.

Habermas, J. (1989). The Structural Transformation of the Public Sphere. Cambridge, MA: MIT Press.

Habermas, J. (1996). Between Facts and Norms: Contributions to a Discourse Theory of Law and Democracy, Cambridge, MA: MIT Press. 
Hernández Gascón, J. M., Fontrodona Francoli, J. \& Pezzi, A. (2005). Mapa de los Sistemas Productivos Locales Industriales en Cataluña, Barcelona: Generalitat de Catalunya.

Karlsen, J. (2007). The Regional Role of the University: A Study of Knowledge Creation in the Agora between Agder University College and Regional Actors in Agder, Norway, PhD Thesis, Trondheim: Norwegian University of Science and Technology.

Kelly, Ursula, McLellan, Donald, and McNicoll, lain. (2006). The Economic Impact of UK Higher Education Institutions: A Report for Universities UK, Glasgow: University of Strathclyde.

Kelsey, J. (1998). 'Privatizing the Universities', Journal of Law and Society, 25: 1, 51-70.

Laredo, P. (2007). 'Revisiting the Third Mission of Universities: Toward a Renewed Catergorization of University Activities', Higher Education Policy, 20, 441-56.

Layard, R. (2006). 'Happiness and Public Policy: A Challenge to the Profession', The Economic Journal, 116: March, C24-C33.

Lazzeretti, L \& Tavoletti, E. (2005). 'Higher Education Excellence and Local Economic Development: The Case of the Entrepreneurial University of Twente', European Planning Studies, 13(3), 475-93.

Lenton, Pamela (2007). Global Value. The Value of UK Education and Training Exports: An Update, London: British Council.

Levin, M. \& Greenwood, D. J. (2008). 'The Future of Universities: Action Research and the Transformation of Higher Education', in P. Reason \& $\mathrm{H}$. Bradbury (eds.) The SAGE Handbook of Action Research: Participative Enquiry and Practice, second edition, London: Sage Publications.

Lucas, Robert E. Jr. (1988). 'On the Mechanics of Economic Development', Journal of Monetary Economics, 22: 3-42).

Lundvall, B-A. (2002). The University in the Learning Economy, Danish Research Unit for Industrial Dynamics (DRUID) Working Paper Number 0206.

Lundvall, B-A. (1992). National Systems of Innovation. Towards a Theory of Innovation and Interactive Learning, London: Pinter. 
Mankiw, Gregory N., Romer, David and Weil, David, N. (1992). 'A Contribution to the Empirics of Economic Growth', The Quarterly Journal of Economics, 107: 2, 407-437.

Marchak, M. P. (1993). The Integrated Circus: The New Right and the Restructuring of Global Markets, Montreal and Kingston: McGill-Queens University Press.

Morgan, K. (1997). 'The Learning Region: Institutions, Innovation and Regional Renewal', Regional Studies, 35(5): 491-503.

Morgan, K. (2004), 'The Exaggerated Death of Geography: Learning, Proximity and Territorial Innovation Systems', Journal of Economic Geography, 4, 321

Nelson, R. R. (ed.) (1993). National Systems of Innovation, Oxford, Oxford University Press.

OECD (2007). Education at a Glance 2007: OECD Indicators, Paris: OECD.

Ohmae, K. (1995). The End of the Nation State: The Rise of Regional Economies, London: HarperCollins.

Pike, Andy (2007). 'Editorial: Whither Regional Studies?', Regional Studies, 41: 9, 1143-1148.

Porter, Michael E. (1990). The Competitive Advantage of Nations. London: The MacMillan Press.

Psacharopoulos, George (1994). 'Returns to Investment in Education: A Global Update', World Development, 22: 9, 1325-43

Psacharopoulos, George and Patrinos, Harry A. (2002). 'Returns to Investment in Education: A Further Update', World Bank Policy Research Working Paper No. 2881, Washington, D.C.

Reason, P. \& Bradbury, H. (2008). 'Introduction', in P. Reason \& H. Bradbury (eds.) The SAGE Handbook of Action Research: Participative Enquiry and Practice, second edition, London: Sage Publications.

Roberts, P. (1999). 'The Future of the University: Reflections from New Zealand', International Review of Education, 45: 1, 65-85.

Romer, Paul M. (1989). 'Human Capital and Growth: Theory and Evidence', National Bureau of Economic Research Working Paper Number 3173, Cambridge, MA. 
Scholte, J. A. (2000). Globalization: A Critical Introduction, Basingstoke: Palgrave.

Scott, Allen J. (1998). Regions and the World Economy: The Coming Shape of Global Production, Competition and Political Order, Oxford: Oxford University Press.

Sklar, H. (Ed.) (1980). Trilateralism: The Trilateral Commission and Elite Planning for World Management, Boston: South End Press.

Sparkes, A. C. (2007). 'Embodiment, Academics and the Audit Culture: A Story Seeking Consideration', Qualitative Research, 7(4): 521-550.

Storper, Michael (1997). The Regional World: Territorial Development in a Global Economy, London: Guildford Press.

Sugden, R. (2004). 'A Small Firm Approach to the Internationalisation of Universities: A Multinational Perspective', Higher Education Quarterly, 58(23), 114-35.

Sugden, R. and Wilson, J. R. (2005). 'Economic Globalisation: Dialectics, Conceptualisation and Choice', Contributions to Political Economy, 24: 1332.

Temple, Jonathan (1999). 'The New Growth Evidence', Journal of Economic Literature, 37: 1, 112-156.

Tirole, J-J. (1988). The Theory of Industrial Organisation, Cambridge, Massachusetts: MIT Press.

Wilson, J. R. (2009, forthcoming). 'Higher Education and Economic Development: Do We Face and Intertemporal Trade-off', in S. Sacchetti \& R. Sugden (eds.) Knowledge in the Development of Economies: Institutional Choices Under Globalisation, Cheltenham: Edward Elgar.

World Economic Forum (2008). The Global Competitiveness Report 2008-2009, Geneva: World Economic Forum. 


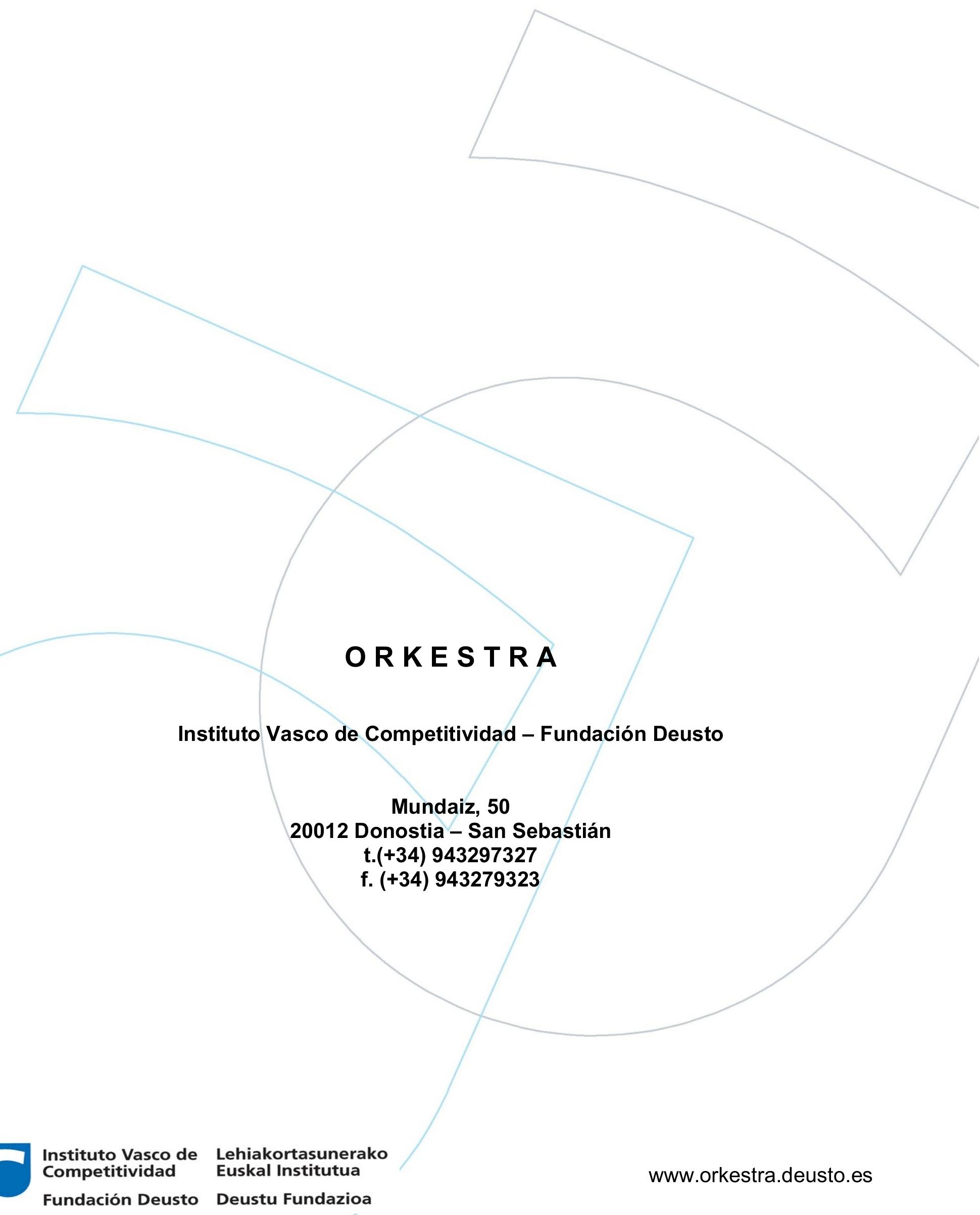

